\title{
PRODUCTIVE ACTIVITIES OF MONASTERIES AS RELIGIOUS TOURISM PRODUCTS
}

\section{Christos Petreas}

'Synodical Office for Pilgrimage Tours and Development of Religious Tourism of the Holy Synod of the Church of Greece

\section{Abstract:}

The "religious interest tourism product" primarily refers to pilgrimage visits to shrines, places of worship, liturgical celebrations and includes religious events and traditions, while internationally some other activities are also considered.

A research in Greece on the popularity of excursions demanded of travel agencies to religious and pilgrimage sites, has identified a number of areas, including both known tourism destinations but also specific religious shrines and has also revealed the organizing entities of religious stakeholders.

As evidenced from the results of another survey conducted in the Dioceses of the Church of Greece, organized religious administrations, particularly monasteries, have added to their purely religious tasks, primarily as a means of support, activities such as, land cultivation, crops raising, candle making, iconography, and other handicrafts, as well as production of saleable products for the religious use such as incense and rosaries, or for home use including food and beverage products.

These activities, while initially, have not been undertaken with the thought of selling to the pilgrims and visitors, in many cases have developed into important revenue sources for the Monastic brotherhoods and for the local religious administrations, and some of these products are of renowned quality, sold widely.

Thus, the paper summarizes selected characteristics of the pilgrimage activity in Greece, both from the religious and from the tourism aspect.

\section{Keywords:}

Religious tourism, monastery products, pilgrimage activities, Greece.

\section{INTRODUCTION}

The "religious interest tourism product" refers to pilgrimage visits to shrines, places of worship, liturgical celebrations and includes religious traditions, anniversary events, and cultural characteristics. Internationally, it also includes some more specialized activities: conferences, missionary trips, evangelical gatherings, etc. (UNWTO 2007). These "dimensions" of travel for religious interests are underlying and affect its touristic development.

Tourism development has changed from an emphasis on consuming what was offered to what is now demanded or desired by the
Correspondence:

Christos Petreas

e-mail:

c.p.petreas@gmail.com 
travelers over the last few decades. Thus, special interests of travelers are now motivators for the determination of the offered products and services (Petreas 2005).

So, tourism has kept on and we are now at a situation where we are looking at a "new tourism", where the key words that describe it are: experience, specialization, technology, information, interests, and value for money, quality, and sustainability.

Religious tourism has been practiced since the ancient times. Theism, worship and blessing have always been motives for travel since the early dawns of history, much before the tourism development and they will probably continue being so. We shall review the religious visitation - pilgrimage activity from the tourism scope, as one of the special interest tourism activities.

\section{THE MARKET OF RELIGIOUS TOURISM}

Why indeed are we interested in religious tourism? More than 2/3 (88\%) of the World Heritage sites have a religious significance, while the visitation of religious monuments is a part of the normal tourists' behavior (Shackley 2000). Approximately $75 \%$ of all inhabitants of the planet belong to the five most important religions. In Europe there are over a half million religious buildings (churches, temples, mosques, synagogues, etc.), most of which have a long history, a high heritage value and rich artistic content (Future for Religious Heritage 2014).

The World Religious Tourism Association (WRTA 2009) identifies three primary reasons for this growth of the religious tourism. One reason is the increase of the overall number of travelers worldwide. Secondly, there seems to be an increasing number of people who wish to show their faith, and act accordingly and thirdly, there are many ways that people include their beliefs in their everyday life and a part of that includes not only participation in religious events, but also attending religious presentations (such as participations in Evangelical gatherings in North America). It has been argued by the WRTA that religious tourism is worth more than $\$ 18$ billion and handles more than 300 million travelers (Tourism Tidbits Archive 2014). I would like to add that there are 300 million travelers in the Western world, and there are more than double that number in the East Asia and South-East Asia among Buddhists, Hindus and so on.

In a special survey among Europeans in 8 countries (Future for Religious Heritage 2014) carried out to provide insights on how Europeans relate to churches and other religious buildings, it was reported that 4 out of 5
Europeans deemed religious heritage buildings essential for community life, and wanted to promote them to the secular society. Furthermore, $87 \%$ believed that churches and religious buildings should be open to tourism if they contain architectural or artistic treasures.

For many years, a distinction has been proposed by Smith (1992) with regard to the motives of the "religious tourist" between the two polarities of "secular" and "sacred". But a wider approach to religious tourism can cover various activities, and can be categorized as (a) Pilgrimage visit, (b) Cultural visit (c) Religious celebrations and events (d) Other - conferences, missionary trips, religious camps.

We also note that negative aspects of the visitor experience on religious sites have been identified by Woodward (2004) such as overcrowding, insufficient services, and others. It has also been proposed to separate areas for worshippers and non-worshippers in "religiously active" sites or shrines.

Recent (2014) research on religious tourism in Italy by ISNART - the Italian Institute for Research on Tourism Flow indicated that $16 \%$ of religious tourism in Italy is from tourists abroad. It identified the characteristics of the "religious visitors" as presented in the following Table.

Table 1. Characteristics of religious tourists in Italy (2014)

\begin{tabular}{cc}
\hline $41 \%$ & $30-50$ years old \\
\hline $32 \%$ & travel with a companion \\
\hline $20 \%$ & choose organized package tours \\
\hline $20 \%$ & travel in a friendly group \\
\hline $13 \%$ & are "family travelers" \\
\hline$<10 \%$ & travel alone \\
\hline
\end{tabular}

Source: ISNART 2014

\section{CHARACTERISTICS OF THE RELIGIOUS VISIT}

Certain characteristics have been identified in the organization and implementation of the "religious visit". Field research on one of the most popular sites, Meteora, has indicated potential conflict areas related to the interaction of the various stakeholders involved.

In a research among travel agents in Greece, the indication is that about $30 \%$ of the tours they arrange include or are solely dedicated to pilgrimage excursions (Petreas 2014). The research shows that the most popular destinations of these tours are of course all over Greece, but we have to consider, among others, specifically some that are identified as religious sites that 
$76 \%$ desired or demanded, namely Meteora. Meteora is the most visited religious site in Greece. It attracts more than a million tourists annually and this year with the big increase it will probably draw more than a million and a half.
In the diagram below, the most popular religious destinations in Greece are presented

Patmos, Tinos and Zakynthos are three islands with a high level of desired tours and are also touristic islands, as of course are all the other destinations that include religious pilgrimages.

Table 2. The most popular religious destinations in Greece

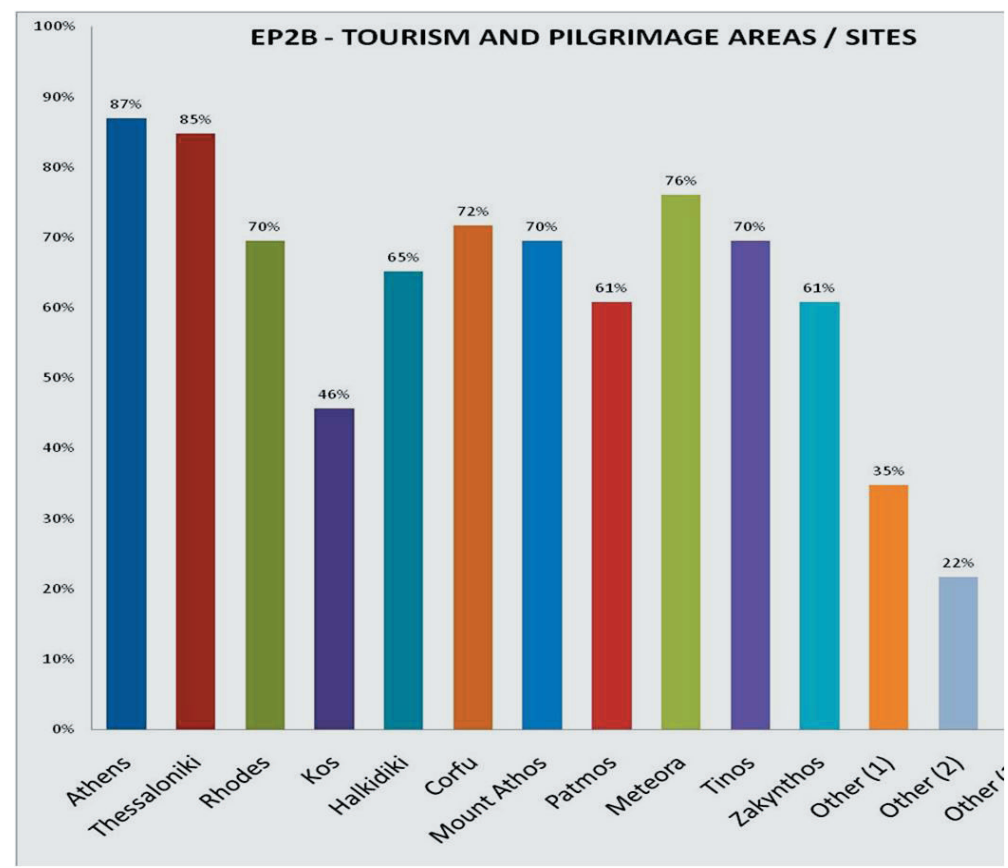

Source: Petreas, 2014

On the other hand, on examining what type of tourism, religious tourism, we have in Meteora, we have noted that Meteora is not only visited for its religious characteristic, but much more for the monasterie's cultural values, the natural environment, the arts, the architecture of the monasteries and the uniqueness of the site. The site has been listed on the UNESCO list of World Cultural Heritage.

The data from a research in Meteora (Petreas et al 2005a, 2009) indicate that just under $60 \%$ of individual visitors, or individually arranged visits, stay in hotels, as opposed to $40 \%$ group visits. New (first time) arrivals are at about $73 \%$, while only about $27 \%$ are repeaters. Foreign visitors comprise more than $2 / 3$ of the visits to Meteora.

It is interesting that when we ask "What are the primary activities tourists came to the Meteora area for?", we found out that concerning religious visitation, a great majority were the overnighters, those that stayed at least one night, making up percentage of $94 \%$, as opposed to only $78 \%$ of those that came for a day visit. The Meteora area visits also include business tourism, eco-tourism, and outdoor activities. Meteora is also popular as a location for climbing, nature based activities, various sports in addition to general cultural reasons for a visit. Of course there is a smaller portion of those visiting friends and relatives and second home activities (Petreas et al 2005a, 2009). The analysis is presented in the following Table.

\section{THE DEVELOPMENT OF PRODUCTIVE ACTIVITIES BY MONASTERIES}

During the religious visits to different shrines and monasteries, it has been a practice in the recent years to also visit a "religious shop - exhibition" where a variety of religious items and religious products are offered for sale, as well as, in some cases, food and beverage items produced at the Monastery. 
In a specialized research survey carried out with the blessing of the Holy Synod of the Church of Greece, which reviewed aspects of the Dioceses' activities in addition to pilgrimages and religious interest tourism, it was reported (Petreas 2016) that a number of them, and particularly monasteries, have added to their purely religious tasks, primarily as a means of support, activities such as, land cultivation, crops raising, candle making, iconography, and other handicrafts, as well as a production of saleable products, for religious use such as incense and rosaries, or for home use, including food and beverage products.

Greece has a total of about a hundred dioceses and they are operating as autonomous religious administrations. In the recent years, various Dioceses have taken advantage of the increasing interest in pilgrimage and religious tourism, particularly in areas or shrines or sites that are well known, and have stimulated increased visitations by including information on the web sites of particular religious sites and by encouraging religious groups to make visits.

In a recent survey that was administered under the auspices of the Committee for Pilgrimage Tourism of the Holy Synod of the Church of Greece (Petreas 2016), the details of the available physical facilities were examined. The Dioceses reported that $60 \%$ do have a monastery guesthouse, about $42,5 \%$ have a Religious Museum, basically displaying ecclesiastic relics, icons, other religious articles as well as vestments. It is interesting that about $30 \%$ include a multi-purpose hall (some more than one) that is used to host conferences or other events, primarily of religious nature or presentations. Additionally, 37\% of the Dioceses of the Church of Greece reported they maintain Libraries some of which are very important with unique exhibits and contents.

Based on the survey results and on discussions with a number of Dioceses and Monasteries, we can identify the elements in the structure of the visit to the religious monuments or sites. Basically, there are 5 elements:

- The reception and visit to the Church, Shrine, or site, by pilgrims or general visitors

- The elements and the presentation of the history, worship and traditions

- The reverence of the holy miraculous icons, saints' relics and other sacred items

- The display of holy relics, or religious items in museums or collections

- The element of accommodation in monastic cells, hostels or pilgrim houses for staying at the monastery and participating in the monastic life.

Table 3. Comparison of " 1 st Priority" activities of visitors to Meteora area

\begin{tabular}{|c|c|c|}
\hline $1^{\text {st }}$ priority only & 2004 data all tourists & 2009 data overnighters \\
\hline Business tourism & $20 \%$ & $10 \%$ \\
\hline Eco-tourism activities & $19 \%$ & $6 \%$ \\
\hline Religious visitations & $78.6 \%$ & $94 \%$ \\
\hline Outdoor activities $^{[1]}$ & $14.3 \%$ & $24 \%$ \\
\hline Nature based activities & $6.7 \%$ & $18 \%$ \\
\hline Athletic / sport activities ${ }^{[2]}$ & $11.1 \%$ & $21 \%$ \\
\hline Cultural activities & $14.3 \%$ & $33 \%$ \\
\hline Friends/ relatives & N.A. & $10 \%$ \\
\hline Second Home & N.A. & $4 \%$ \\
\hline
\end{tabular}

Source: Petreas et al 2005a, 2009,

Monasteries have also reported that on certain occasions, by prior arrangements, they provide special services and even perform marriages or baptisms in addition to welcoming visitors, particularly those staying at the monastic accommodations, to attend the programmed services.

It has been reported that religious services are offered by about $60 \%$ and include various Liturgies which pilgrims participate in or attend, while $42 \%$ are reserved for specific sacraments, marriages, baptisms and so on.
All pilgrimages and shrines have reported having promotional material (some of which may even be sold at the religious shops). It has been reported that more than $80 \%$ have printed material and almost $70 \%$ also have internet web services or websites, evidencing that the Church is actively keeping up with the technology.

As regards specifically the monastery productive activities and products, based on the results of the above surveys, we have been able to distinguish four categories: 
1. Candles and related products, incense and similar are produced by $27 \%$ of the different reporting Dioceses

2. Food products, including production for the use of the Monastery, but also in many cases available to be sold to pilgrims in Monastery Shops or at the souvenir locations constitute $37 \%$.

3. Production of ecclesiastical products, such as incense and particularly holy vestments which are not used by the general public, make up 35\% and,

4. All the other types of products of religious nature, including the design of icons, other particular religious decorations and liturgy utensils constitute $32 \%$.

Therefore we can see that about or a little over one third of the religious administrations and organizations overall, actively promote products for sale to support their income. We must note that a number of Monasteries or Church organizations are involved in the productive activities of more than one category, and in this sense the activities are performed by more than the indicated estimate of one third.

A small percentage of the Dioceses (particularly those with the more known pilgrimage sites) have reported hosting and receiving tours of journalists, travel agents and other professionals for the promotion of the sites. This is an activity the Synodical Office for Pilgrimage Tours is responsible for and indeed it has undertaken it, including hosting particular visits of religious officials not only from Greece but from other countries.

\section{CONCLUSION}

We should, therefore, examine the religious sites and shrines from two approaches: (1) the touristic approach, which the tourism stakeholders are interested in, and (2) the religious functionality of the site, which is the primary interest of the religious Authorities. These approaches differentiate the corresponding responsibilities and the conflicts of the "use" of the religious site - shrine: the touristic approach which deals with the accessibility, facilitation of the visit and promotion as a tourist attraction, and the ecclesiastical approach which requires that the site be managed with the applications of religious regulations, dress code, visiting hours, photographic restrictions, veneration of relics, etc.

From the research results and the actual experience of visiting different pilgrimage and religious sites, we can distinguish six factors that need to be considered with respect to the religious visit:
1. The adherence to the religious character of the site or monument or object

2. The spiritual elements of the pilgrimage of the visitor's faith

3. The integration relationship and social balance of the attraction of the site or shrine, in the area's local economy and activities

4. The commercial needs of the tourism enterprises operating in the area

5. The dual identity, because in some cases the shrine or church or monastery is also a practicing monastery not just a visiting area or building

6. The physical integrity and maintenance of the religious site or monument or object.

In the survey of the tourism enterprises in the Meteora area (Petreas 2005) over 90\% of the respondents indicated the need to attract foreign visitors, and to provide information on the availability of visits and actions to valorize religious monuments. More than 75\% of respondents have included other proposals, such as improvement of road and road network. More than $50 \%$ indicated the need for expanding the promotional activities and internet marketing and supporting the development of the surrounding region so the visitor has something to do in addition to visiting the religious sites.

Now, twelve years later (2017), we note that the need to attract foreign visitors is still valid. As regards other proposals, the road network has been substantially improved, the Internet marketing is quite extensive, and efforts are being taken to provide other activities for visitors in addition to or apart from the visits to the monasteries.

\section{ACKNOWLEDGMENT}

We are indebted to the President and Members of the Synodical Office for Pilgrimage Tours of the Holy Synod of the Church of Greece for their approval of the proposals for the surveys conducted with the blessing of the Church. 


\section{REFERENCES}

Future for Religious Heritage. (2014, May). Secular Europe backs religious heritage - Survey Report. Retrieved from www. frh-europe.org.

ISNART - Italian Institute for Research on Tourism Flow. (2014). Religious tourism in Italy in 2014. Retrieved September 2017 from http://www.eturbonews. com/45662/ religious-tourism-during-2014-record -typically- held-italians .

Petreas, C. (2016). Presentation of results of the special research on the pilgrimage activities of the Holy Dioceses and on ecclesiastic and monastic product in The Holy Diocese of Kitrous, Platamon and Ekaterini. (Ed.). Proceedings of the 2nd Panhellenic Conference on Pigrimage Tours Pilgrimage tours as a tool for tourism development - The case of Pieria. NPC: Indianapolis.

Petreas, C. (2014). Development of Religious and Pilgrimage Destinations: The Case of Meteora. The Proceedings of the UNWTO 1st International Congress on Religious heritage and tourism: types, trends and challenge. pp. 216-220. UNWTO and City of Elche: Elche Spain. Retrieved from http://www.eunwto.org/doi/ abs/10.18111/9789284416684.

Petreas, C. (2009). The Lingering Potential of Religious Tourism for Greece. Paper presented at the 2nd European Tourism Conference, Thessaloniki, Greece, October 30-31, 2009.
Petreas, C. (2005). Development of Tourism Niche Market Segments in the Regions of Romania. The International Tourism Conference. Development Agency of the Region of Central Romania: Soyata, Romania

Petreas, C. et al. (2005). Final Report "Study for the Tourism Development Prospects of the greater area of Meteora and the Municipality of Kalambaka"; the project covered the analysis, evaluation and proposals for the further development of the tourism sector in the region, Municipality of Kalampaka 2005.

Shackley, M. (2001). Visitor Management. Routledge: UK

Smith, V. L. (1992). Introduction: The Quest in Guest. Annals of Tourism Research. 19 (1), 1-17.

Tourism Tidbits Archive. (2014). The importance of the religious tourism market. Retrieved September 2017 from http://www.tour- ismandmore.com/tidbits/ the-importance-of-the-religious-tourism-market/.

UNWTO. (2007). A Contribution to the Dialogue Among Religions, Cultures and Civilizations. The Cordoba International Conference. International Conference on Tourism, Religions and Dialogue of Cultures; Cordoba, Spain, 29-31 October 2007, UNWTO.

Woodward, S. (2004). Faith and tourism: planning tourism in relation to places of worship. Tourism and Hospitality Planning \& Development. 1(2), 173-186. 